\title{
Optimization of Dye Removal from Textile Wastewater using Activated Carbon from Sawdust
}

\author{
O. A. A. Eletta ${ }^{1 *}$, S. I. Mustapha ${ }^{1}$, O. A. Ajayi ${ }^{2}$, A. T. Ahmed ${ }^{1}$ \\ ${ }^{1}$ Department of Chemical Engineering, University of Ilorin, Ilorin, Nigeria. \\ ${ }^{2}$ Department of Chemical Engineering, Ahmadu Bello University, Zaria, Nigeria.
}

\begin{abstract}
This study is aimed at developing an adsorbent from sawdust for optimum removal of dye from textile wastewater. The adsorbent was developed, characterised and, the adsorptive capability for the removal of dye was determined by optimizing the process parameters (adsorbent dosage, contact time and agitation speed) using Response Surface Methodology. The physical and chemical characterization of the effluent was carried out before and after the adsorption studies. From the results, a maximum adsorption capacity of $98.5 \%$ was obtained at the optimized conditions of $1.5 \mathrm{~g}, 90 \mathrm{~min}$ and $275 \mathrm{rpm}$ for adsorbent dose, contact time and agitation speed respectively. The ANOVA of the regression model showed that the model is highly significant with $\mathrm{R}^{2}$ of 0.98 . Further analysis carried out revealed that, in addition to dye removal, trace metals were also adsorbed in the process. This fact was established when the concentration of copper in the wastewater was found to decrease from $0.09 \mathrm{ppm}$ to $0.03 \mathrm{ppm}$ corresponding to $66.7 \%$ removal at the end of the process.
\end{abstract}

KEYWORDS: Pollution, Wastewater, Textile, Adsorption, ICP-MS, Optimization, Trace metal

[Received October 13 2017; Revised December 7 2017; Accepted December 20 2017]

\section{INTRODUCTION}

Water is one of the most important resources of man; however, this often gets polluted through the activities of man either directly or indirectly. With advancement comes growth in industrial activities and one very prominent industry is the textile industry where different types of fabrics are produced. This industry has been implicated in the pollution of both surface and groundwater depending on the depth of the groundwater (Hettige and Mowjood, 2015; Wang et al., 2007). The textile industry has always been known to use large quantities of water and chemicals in its operations some of which eventually get discharged with the wastewater into the environment and mainly water bodies. Dyes which constitute a major component of these discharges are readily visible, even when present in small quantities because of their brilliance (Pang and Abdullah, 2013; Robinson et al., 2001).

Industrial effluents containing synthetic dyes have been implicated in the reduction of light penetration in rivers and thus affect photosynthetic activities of the aquatic flora leading to a decrease in food for the aquatic organisms (Jin et al., 2007; Pereira and Alves, 2007).

Many of these dyes are toxic and pose a serious hazard to aquatic animals and eventually man, who ends up consuming these. Wastewater containing dyes contains recalcitrant organic molecules, which are resistant to aerobic digestion, very stable to light, oxidizing agents and, very difficult to treat (Sun and Yang, 2003). Reactive dyes are used to dye cotton materials which make up about $50 \%$ of the world's fibre consumption and, they are problematic as, they tend to pass through conventional treatment systems unaffected (Allègre et al., 2006).

*Corresponding author's e-mail address: modeletta@hotmail.com
Different methods have been employed in the removal of colour from textile wastewater; whole bacterial cells have been employed in the removal of colour from textile wastewater (Pearce et al., 2003). Other methods used include ozonation, chemical precipitation, flocculation, photolysis and ion-pair extraction and biological processes (Grant and Buchanan, 2000). Many of these are very expensive and require considerable start-up costs. Biodegradation process requires strict conditions to be maintained and sometimes can be very difficult to operate on a large scale (Bhole et al., 2004).

Extensive research has been carried out on the removal of dyes from textile wastewaters using adsorption due to its simplicity and efficiency in the removal of pollutants that are too stable for biological methods (Kyzas et al., 2013). Adsorbents used are varied such as charcoal, bentonite, silica, peat, natural zeolites, waste from agriculture; sawdust, fly ash, lignocellulosic materials, etc. The replacement of synthetic compounds with unconventional, natural or biological materials (green or environmentally friendly) has become the subject of considerable interest (Suteu et al., 2008).

The modification of natural materials or agricultural byproducts has shown promising results in improving their capacity and selectivity towards the removal of specific pollutants from various wastewater. There are several studies on the use of sawdust confirming the effectiveness of sawdust for the removal of dyes from wastewater; neem sawdust has been used to remove malachite green from dye via adsorption. The authors after varying different process parameters concluded that the neem sawdust shows significant adsorption capacity for malachite green under suitable experimental doi: http://dx.doi.org/10.4314/njtd.v15i1.5 
conditions (Khattri and Singh, 2009). The removal efficiency of activated carbon prepared from coir pith for three highly reactive dyes has been investigated.

The kinetics of the removal was studied and, it was concluded that the activated carbon prepared from coir pith was a suitable adsorbent for the removal of reactive dyes from both synthetic and textile effluents (Santhy and Selvapathy, 2006). Activated carbon prepared from mahogany sawdust has been confirmed effective for the removal of direct dyes (Malik et al., 2007); Oil palm and fibre husk activated carbon has been used in the adsorption of basic dyes. The kinetics, equilibrium and thermodynamic studies have shown the effectiveness of these otherwise waste materials in the removal of the dye (Tan et al., 2008; Tan et al., 2007). The optimization of the adsorption of reactive dyes from textile wastewater using readily available, sawdust modified with $\mathrm{Al}^{3+}$ to remove dyes is not available in the literature. This study examines the treatment of effluent from a textile industry in Kano State, Nigeria.

This research aims to prepare a modified adsorbent from sawdust for the optimal removal of dyes from the textile wastewater, and the specific objectives are to:

- Develop and characterize the adsorbent prepared;

- Optimize the process variables (adsorbent dosage agitation speed and time) for the optimal removal of dyes from the textile wastewater; and

- Determine the adsorptive capacity of sawdust for the removal of dyes from textile wastewater.

\section{MATERIALS AND METHODS}

\section{A. Materials}

The textile wastewater used in this research was collected from a textile industry in Kano, Nigeria while the sawdust samples was collected from a sawmill in Ilorin, Kwara State, Nigeria. Aluminium sulphate, $\mathrm{Al}_{2}\left(\mathrm{SO}_{4}\right)_{3}$, was obtained from a chemical store in Ilorin, Kwara State. The equipment and apparatus used include Atomic Absorption Spectrophotometer (AAS), a jar test apparatus, an Inductively Coupled Plasma Mass Spectrophotometer (ICP-MS), a muffle furnace, a turbidimeter, a mechanical shaker, a weighing balance, a set of sieves, and glassware.

\section{B. Sample Collection and Pretreatment}

The collected sawdust sample was sieved to obtain particles that will pass through a $1 \mathrm{~mm}$ sieve size. The particles were washed with distilled water to remove the surface adhering particles and were sun-dried for $48 \mathrm{~h}$ to reduce the moisture content.

\section{Preparation of Adsorbent}

The prepared sawdust was calcined in a muffle furnace (Carbolite CWF 1200) at $500^{\circ} \mathrm{C}$ for one hour (Malik et al., 2007). An activation solution was prepared by dissolving 2.0 $\mathrm{g}$ of $\mathrm{Al}_{2}\left(\mathrm{SO}_{4}\right)_{3}$ in $100 \mathrm{ml}$ of distilled water. This solution was added to $10.0 \mathrm{~g}$ of the calcined sawdust and, shaken on a mechanical shaker (HY-4 Reciprocated shaker, Zenith Lab).
Thereafter, the mixture was left for $12 \mathrm{~h}$, filtered, and washed several times with distilled water until the $\mathrm{pH}$ was 7.0. The activated sawdust was then dried in an oven at $100^{\circ} \mathrm{C}$ untill a constant weight was attained; this was then cooled in a desiccator.

\section{Characterization of Adsorbent}

The adsorbent (activated sawdust) was characterized using Fourier Transform Infrared (FTIR) Spectroscopy Technique to determine surface functional groups present. The FTIR analyses before and after dye adsorption were carried out on the samples using Shimadzu FT-IR-8400S Spectrophotometer with a resolution of $4 \mathrm{~cm}^{-1}$ in the range of $4000-500 \mathrm{~cm}^{-1}$.

\section{E. Effluent Characterization}

The collected textile wastewater was used to evaluate the effectiveness of the prepared activated carbon moved dye from textile wastewater. The $\mathrm{pH}$, the turbidity, the colour and the presence of trace metals in the textile effluent was determined before and after the adsorption process. The physical properties of the textile effluent such as the $\mathrm{pH}$, and the turbidity were analyzed using a digital $\mathrm{pH}$ meter (Model KL-031) and a turbidimeter (HACH 2100NTU Turbidimeter) respectively.

The presence of trace metals was established using an inductively coupled plasma mass spectrometry (ICP-MS) and an atomic absorption spectroscopy (AAS). The Inductively Coupled Plasma Mass Spectrometer (ICP-OES iCAP6500 DUO, Thermo Scientific, UK) equipped with a charge injection device (CID) was used in the determination of metal ions present in the wastewater sample. The wastewater analysis using ICP-MS was carried out in the Analytical/Environmental Laboratory at the University of Johannesburg, South Africa. The specifications at which the ICP-MS operated are as shown in Table 1.

\begin{tabular}{ll} 
Table 1: Operating Conditions of the ICP-MS. \\
\hline Parameters & Condition \\
\hline RF generator power (W) & 1150 \\
Coolant gas flowrate $\left(\mathrm{Lmin}^{-1}\right)$ & 12 \\
Carrier gas flow rate $\left(\mathrm{Lmin}^{-1}\right)$ & 0.7 \\
Auxiliary gas flow rate $\left(\mathrm{Lmin}^{-1}\right)$ & 1.0 \\
Pump rate (rpm) & 50 \\
Plasma mode & Axial \\
Replicate & 3 \\
\hline
\end{tabular}

\section{F. Design of Experiments}

The central composite design (CCD) in response surface methodology was used to carry out the optimization of the studied parameters. The desirability (D) function was employed to obtain the optimum conditions to achieve better response in terms of the dye removal efficiency (Adewoye $e t$ al., 2017). Three independent variables; the adsorbent dosage, the contact time and the agitation speed were used in 
designing the experimental matrix. Each numeric factor was minimum and maximum (factorial points) and the centerpoint. For a three-factor scenario where $n$ is equal to three (3), the small CCD is characterized by 10 , not center points and 5, center points resulting in a total of 15 experiments. The minimum and maximum values for each factor investigated are presented in Table 2.

\begin{tabular}{clcccc}
\multicolumn{6}{c}{ Table 2: } \\
\hline Factors & Variable & Unit & Minimum & Center & Maximum \\
\hline $\mathrm{A}$ & $\begin{array}{l}\text { Adsorbent } \\
\text { dose }\end{array}$ & $\mathrm{g}$ & 0.5 & 1.5 & 2.5 \\
$\mathrm{~B}$ & $\begin{array}{l}\text { Contact } \\
\text { time }\end{array}$ & $\min$ & 30 & 75 & 120 \\
$\mathrm{C}$ & $\begin{array}{l}\text { Agitation } \\
\text { Speed }\end{array}$ & $\mathrm{rpm}$ & 100 & 200 & 300 \\
\hline
\end{tabular}

Design expert version 6.0.8, (Stat - Ease, Inc., Minneapolis, MN 55413, USA) statistical software was used for the model fitting and for the evaluation of the statistical significance of the dye adsorption efficiencies. The dye removal efficiency was calculated using eqn (1).

$$
\% \text { Dye Removal }=\frac{\left(T B_{O}-T B_{i}\right)}{T B_{o}} * 100 \%
$$

where, $T B_{o}$ and $T B_{i}(\mathrm{NTU})$ are the turbidity of the wastewater at initial stage and at equilibrium.

\section{G. Adsorption Experiments}

The removal of dye from the textile wastewater was carried out using the batch method at room temperature. The adsorption studies were carried out for different contact times, adsorbent dosages and agitation speeds. The different combinations resulting in 15 batch experimental runs as determined by the design of experiments using design expert software were followed. The batch experiments were carried out by adding each dosage of activated sawdust (0.5-2.5 g) to $100 \mathrm{ml}$ of the wastewater sample and agitated using the jar test apparatus for the duration of contact time (30 -120 min) and agitation speed (100 - $300 \mathrm{rpm})$.

The mixture was filtered and the filtrate was analyzed for the extent of dye removal using a turbidimeter. The run with the highest dye removal was then utilized for the subsequent studies.

\section{H. Effect of Contact Time and Adsorbent Dosage}

The effect of contact time on dye removal was investigated by performing the experiment at an agitation varied over 5 levels: plus and minus alpha (axial points), speed of $200 \mathrm{rpm}$ for an adsorbent dosage of $2.0 \mathrm{~g}$ and varying the experimental runs for periods of $0,60,90,120$ min respectively

The effect of adsorbent dosage on dye removal was investigated by performing the experiment at an agitation speed of $200 \mathrm{rpm}$ for a period of 75 minutes and using absorbent dosages of $0.5,1.0,1.5,2.0,2.5 \mathrm{~g}$ respectively.

\section{RESULTS AND DISCUSSION}

\section{A. Characterization of Adsorbent}

The infrared spectra of the carbonized-activated sawdust sample before and after adsorption of dye molecules were determined on a Shimadzu FT-IR-8400S spectrophotometer, in the range $400-4000 \mathrm{~cm}^{-1}$. Each sample was prepared using potassium bromide, $(\mathrm{KBr})$. The infrared spectra of the two samples (Figure 1) did not show much difference in the region between 3500 and $3000 \mathrm{~cm}^{-1}$ assigned to $\mathrm{O}-\mathrm{H}$ stretching vibration as they both show very weak peak at the region. The $\mathrm{N}-\mathrm{H}$ stretching vibration was absent as no complementary N$\mathrm{H}$ bending was observed as expected between 1650 and 1600 $\mathrm{cm}^{-1}$.

The aromatic and aliphatic $\mathrm{C}-\mathrm{H}$ stretching were equally observed at $3031-2850 \mathrm{~cm}^{-1}$ as weak peak in both samples.

Moisture peak was present in both samples at $2363 \mathrm{~cm}^{-1}$ however; there was a sharp peak at $1736 \mathrm{~cm}^{-1}$ corresponding to carbonyl stretching of ketone, aldehyde, carboxylic acid or esters in the raw sample before the adsorption which was much reduced in the adsorbed sample. Both samples showed prominent peak of $\mathrm{C}=\mathrm{C}$ unsaturated approximately $1600 \mathrm{~cm}^{-1}$.

The peak at $1438 \mathrm{~cm}^{-1}$ corresponding to $\mathrm{O}-\mathrm{H}$ bending vibration was shifted to a lower frequency $1419 \mathrm{~cm}^{-1}$ in the adsorbed sawdust. The out-of-plane bending vibration at 1365 $\mathrm{cm}^{-1}$ (sharp) of the $\mathrm{C}=\mathrm{C}$ bond had also disappeared in the adsorbed sample probably due to some chemical reactions with the dye molecules. In the fingerprint region, the untreated sample also depicted twin sharp peaks at 1230 and $1216 \mathrm{~cm}^{-1}$ which were absent in the adsorbed sample. Generally, the sawdust that adsorbed the dye exhibited less vibrational peaks which may be due to the interactions of the dye molecules with the available functional groups.

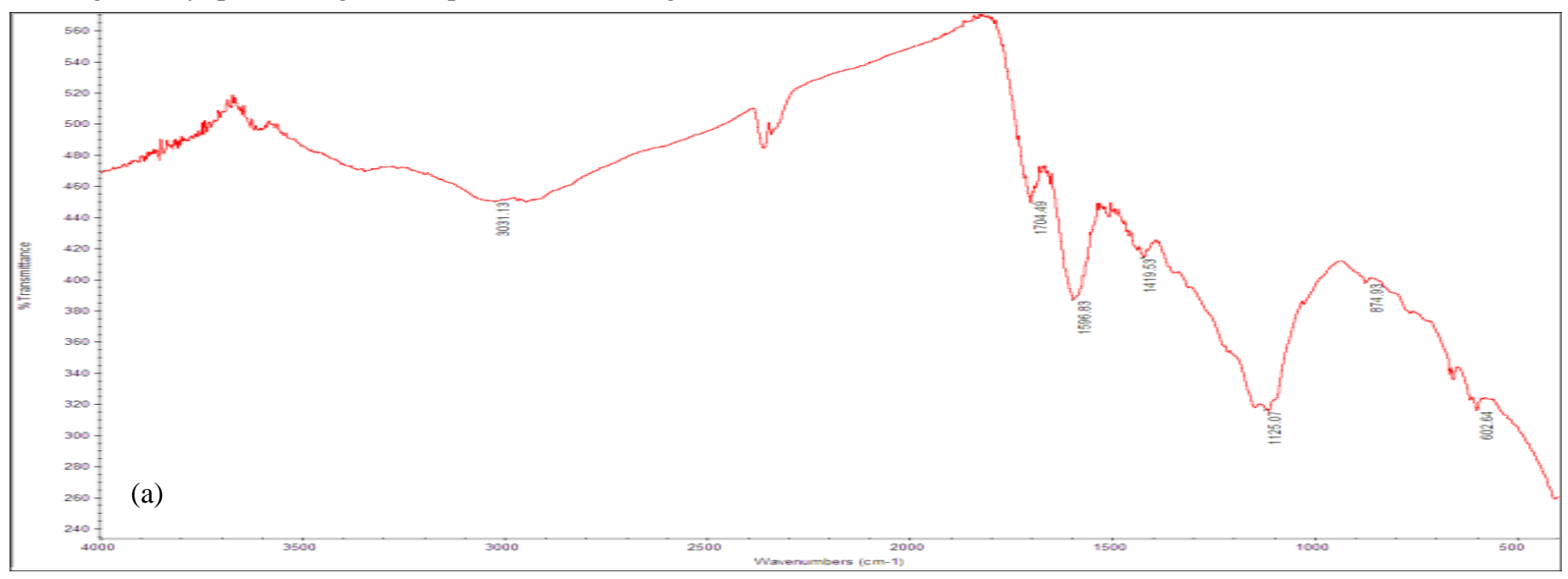




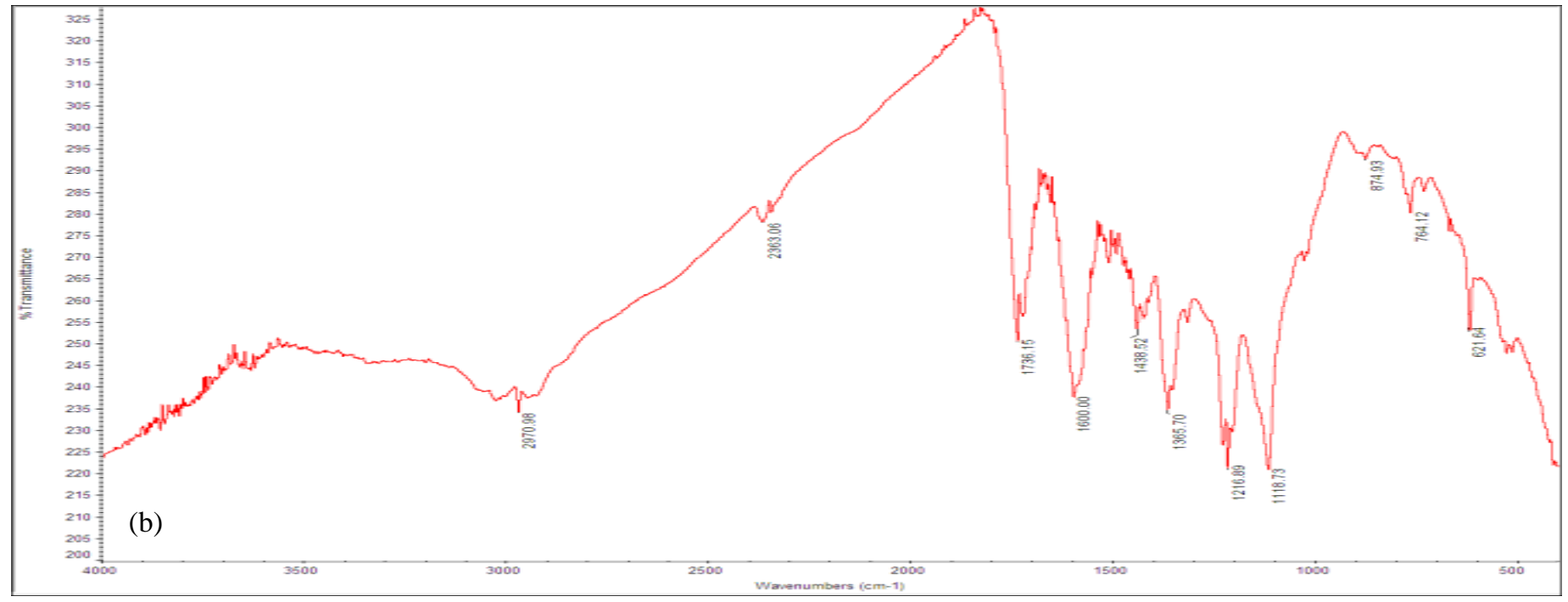

Figure 1: FT-IR Characterization (a) Before Adsorption (b) After Adsorption.

\section{B. Effluent Characterization}

Trace metal analysis was carried out on the raw wastewater sample using an ICP-MS (ICP-OES iCAP6500 DUO, Thermo Scientific, UK) equipped with a charge injection device (CID). The metals detected in appreciable concentrations were $\mathrm{Zn}$ (43.48 ppb), Cu (443.60 ppb), Fe (65.40 ppb), Mn (55.48 ppb) and $\mathrm{Ni}(153.92 \mathrm{ppb})$ as shown in Table 3. Further analyses were performed on the aforementioned elements using an AAS at the Central Research Laboratory at the University of Ilorin, Nigeria. Four (Zn, Fe, $\mathrm{Mn}$ and $\mathrm{Ni}$ ) of the five metals selected based on the significance of their concentration in the raw wastewater (Table 3) were however, found to be below the detection limit of the AAS machine (detection limit: $0.01 \mathrm{ppm}$ ); except for $\mathrm{Cu}$ with concentration of $0.09 \mathrm{ppm}$.

Table 3: Result of raw wastewater analysis from ICP-MS.

\begin{tabular}{cc}
\hline Trace metal & Value $(\mathbf{p p b})$ \\
\hline $\mathrm{Cd}$ & 0 \\
$\mathrm{Co}$ & 1.40 \\
$\mathrm{Cr}$ & 10.84 \\
$\mathrm{Cu}$ & 443.60 \\
$\mathrm{Fe}$ & 65.40 \\
$\mathrm{~Pb}$ & 0 \\
$\mathrm{Mn}$ & 55.48 \\
$\mathrm{Ni}$ & 153.92 \\
$\mathrm{Ti}$ & 2.33 \\
$\mathrm{Zn}$ & 43.48 \\
\hline
\end{tabular}

\section{Design of Experiments}

The design of experiments comprising of the studied factors, their ranges and the response (dye removal efficiency) is presented in Table 4. The response in terms of dye removal efficiency was in the range of $44.0 \%$ to $79.9 \%$.
Table 4: Experimental design matrix for dye removal onto activated sawdust.

\begin{tabular}{ccccc}
\hline Run & \multicolumn{2}{c}{ Independent Variables (Factors) } & Dye removal, \\
\cline { 2 - 4 } & $\begin{array}{c}\text { Adsorbent } \\
\text { Dosage } \\
(\mathbf{g})\end{array}$ & $\begin{array}{c}\text { Contact } \\
\text { time } \\
(\mathbf{m i n})\end{array}$ & $\begin{array}{c}\text { Agitation } \\
\text { Speed (rpm) }\end{array}$ & $\begin{array}{c}\mathbf{Y}_{\text {dye-removal }} \\
\mathbf{( \% )}\end{array}$ \\
\hline 1 & 1.5 & 75 & 200 & 74.7 \\
2 & 2.0 & 75 & 200 & 79.9 \\
3 & 1.5 & 75 & 200 & 74.6 \\
4 & 1.5 & 52.5 & 200 & 55.8 \\
5 & 1.5 & 75 & 150 & 74.0 \\
6 & 1.5 & 97.5 & 200 & 76.6 \\
7 & 1.5 & 75 & 200 & 74.2 \\
8 & 1.5 & 75 & 200 & 74.3 \\
9 & 0.5 & 30 & 100 & 44.0 \\
10 & 1.5 & 75 & 200 & 74.8 \\
11 & 1.5 & 75 & 250 & 78.6 \\
12 & 2.5 & 120 & 100 & 77.0 \\
13 & 0.5 & 120 & 300 & 73.6 \\
14 & 1.0 & 75.0 & 200 & 55.0 \\
15 & 2.5 & 30 & 300 & 52.4 \\
\hline
\end{tabular}

The experimental data were analyzed using CCD and the final empirical model equations showing the relationship between the adsorption process variables and the response was developed as shown in eqn (2).

$$
\begin{aligned}
& Y_{\text {dye } \text { removal }_{\text {r }}}=+72.63+24.90 A+20.80 B+4.60 C- \\
& 13.83 A^{2}-18.83 B^{2}+21.57 C^{2}+3.25 A B+7.25 A C+ \\
& 21.95 B C
\end{aligned}
$$

where $\mathrm{A}, \mathrm{B}$ and $\mathrm{C}$ represents the adsorbent dosage, the contact time, and the agitation speed respectively.

The developed polynomial model equation shows that, the adsorbent dosage (A), contact time (B) and agitation speed (C) have a positive influence on the removal of dye from the wastewater onto the activated sawdust. It also reveals that the interactions of the adsorbent dosage and the contact time $(\mathrm{AB})$, the adsorbent dosage and the agitation speed (AC) and 
the contact time and the agitation speed (BC) all have positive influence on the adsorbance. Of all the terms in the model, only $\left(\mathrm{A}^{2}\right)$ and $\left(\mathrm{B}^{2}\right)$ have negative influence on the adsorption of dye on the activated sawdust. The adequacy and significance of the developed model was evaluated using Ftest and analysis of variance (ANOVA) as shown in Table 5.

From Table 5 , the terms $\mathrm{A}, \mathrm{B}, \mathrm{B}^{2}, \mathrm{C}^{2}$, and $\mathrm{BC}$ were found to be the signficant model terms while $\mathrm{C}, \mathrm{A}^{2}, \mathrm{AB}$, and $\mathrm{AC}$ were insignificant for the dye removal model. A good correlation existed between the experimental and predicted data with an $\mathrm{R}^{2}$ value of 0.98 . This shows that the developed model is reliable.

Table 5: ANOVA of response surface quadratic model for dye removal.

\begin{tabular}{lllllll}
\hline Source & $\begin{array}{l}\text { Sum of } \\
\text { Squares }\end{array}$ & $\begin{array}{l}\text { Degree } \\
\text { of } \\
\text { Freedom }\end{array}$ & $\begin{array}{l}\text { Mean } \\
\text { Square }\end{array}$ & $\begin{array}{l}\text { F- } \\
\text { Value }\end{array}$ & Prob>F & \\
\hline Model & 1764.85 & 9 & 196.09 & 27.15 & 0.0010 & "Significant \\
A & 310.01 & 1 & 310.01 & 42.93 & $0.0012^{*}$ & \\
B & 216.32 & 1 & 216.32 & 29.96 & 0.0028 & \\
C & 10.58 & 1 & 10.58 & 1.47 & 0.2802 & \\
$\mathrm{~A}^{2}$ & 35.59 & 1 & 35.59 & 4.93 & 0.0771 & \\
$\mathrm{~B}^{2}$ & 65.98 & 1 & 65.98 & 9.14 & 0.0293 & \\
$\mathrm{C}^{2}$ & 86.56 & 1 & 86.56 & 11.99 & $0.0180^{*}$ & \\
$\mathrm{AB}$ & 4.99 & 1 & 4.99 & 0.69 & 0.4438 & \\
$\mathrm{AC}$ & 23.36 & 1 & 23.36 & 3.24 & 0.1320 & \\
BC & 214.13 & 1 & 214.13 & 29.65 & $0.0028^{*}$ & \\
Residual & 36.11 & 5 & 7.22 & & & \\
\hline
\end{tabular}

* Values of "Prob > F" less than 0.0500 indicate model terms are significant.

\section{Optimization of Process Parameters}

The optimization of process parameters for the removal dye onto activated sawdust was carried out using design expert software. The target goal of the optimization process was set to maximize dye removal within the experimental range of the studied independent variables. The solution of optimization is usually selected based on the highest desirability or its closeness to unity (Adewoye et al., 2017).

The optimal conditions obtained for adsorbent dose, contact time, and agitation speed were $1.5 \mathrm{~g}, 90 \mathrm{~min}$, and 275 rpm respectively. The dye removal efficiency at optimum conditions was found to be $98.5 \%$. The model validation was carried out and a good agreement existed between the predicted value and the experimental value with relatively small error of $2.3 \%$ as shown in Table 6. Figure $2(\mathrm{a}-\mathrm{c})$ shows the combined interaction of the three studied parameters. The curvatures obtained for all the response surface plots clearly indicated that all the variables, either individually or by way of interaction contributed to the dye removal. However, the level of contributions may differ.

Table 6: Model Validation.

\begin{tabular}{|c|c|c|c|c|c|}
\hline \multirow{2}{*}{$\begin{array}{l}\text { Adsorbent } \\
\text { Dosage, } \\
\text { A } \\
(\mathrm{g})\end{array}$} & \multirow{2}{*}{$\begin{array}{l}\text { Contact } \\
\text { Time, } \\
\text { B } \\
(\min )\end{array}$} & \multirow{2}{*}{$\begin{array}{l}\text { Agitation } \\
\text { Speed, C } \\
(\mathrm{rpm})\end{array}$} & \multicolumn{3}{|c|}{$\begin{array}{c}\text { Dye Removal Efficiency, } \\
Y_{\text {dye removal }}(\%)\end{array}$} \\
\hline & & & Predicted & Exptl & $\begin{array}{c}\text { Error } \\
(\%)\end{array}$ \\
\hline 1.50 & 90.00 & 275.00 & 98.50 & 96.20 & 2.30 \\
\hline
\end{tabular}
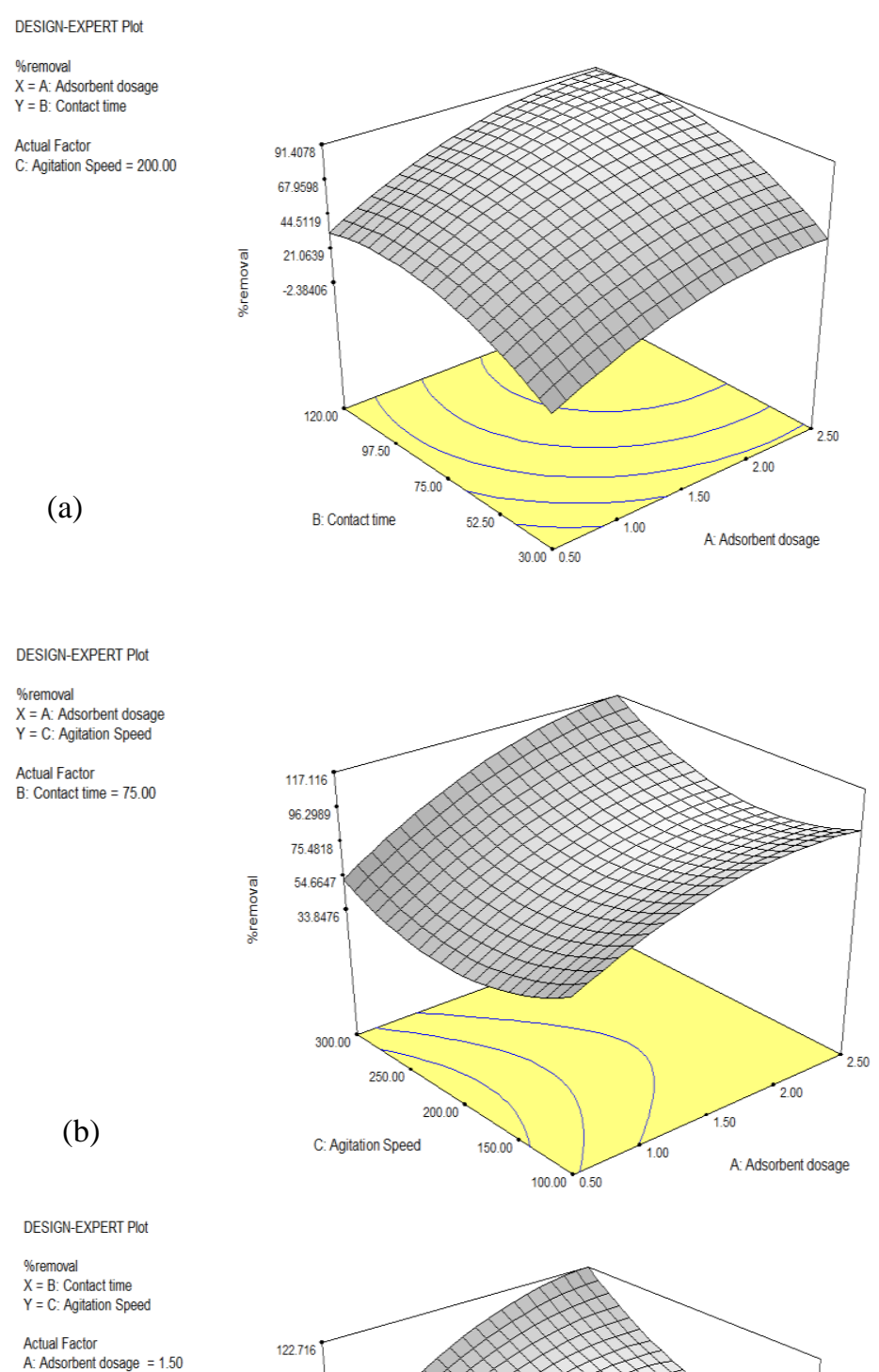

(c)

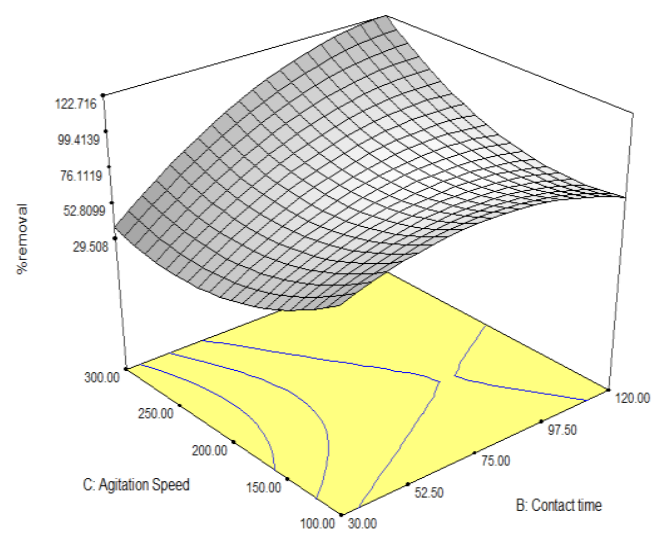

Figure 2: 3D response surface plots: (a) effect of adsorbent dosage and contact time on dye removal (b) effect of adsorbent dosage and agitation speed on dye removal (c) effect of contact time and agitation speed on dye removal.

At the optimum conditions of adsorbent dose, contact time and agitation speed established, the treated effluent was analyzed before and after the adsorption studies. The $\mathrm{pH}$ and turbidity were determined in triplicate and the average values were noted. After the adsorption studies with $\mathrm{Al}^{3+}$ activated sawdust, the $\mathrm{pH}$ of the wastewater was found to decrease from 
8.88 to 7.24 while the turbidity was reduced from 7.90 to 0.3 NTU which translated to $96.2 \%$ dye removal from the wastewater. Trace metal analysis was carried out on the raw wastewater sample and treated sample at optimum condition using the AAS. While all other metals was found to be below detection limit of the AAS available, there was a reduction in the concentration of $\mathrm{Cu}$ to $0.03 \mathrm{ppm}$ showing $66.67 \%$ removal of $\mathrm{Cu}$ which confirms that, besides dye removal, the adsorbent (activated sawdust) was also effective in the removal of trace metals from textile wastewater.

\section{E. Adsorption Experiments}

\section{Effect of Adsorbent Dosage}

Figure 3 shows that dye removal occurs with an increase in adsorbent dosage until at adsorbent dosage of $2.0 \mathrm{~g}$ at which the dye removal was maximum ( $80 \%$ removal). This can be attributed to the increase in surface area and number of active sites and with further increase, there was an observed fall in the percentage removal of dye due to an increase in adsorbent dosage beyond maximum adsorption capacity which might be as a result of overlapping of the adsorption sites due to overcrowding of adsorbent particles beyond the optimum dose (Garget al., 2004).

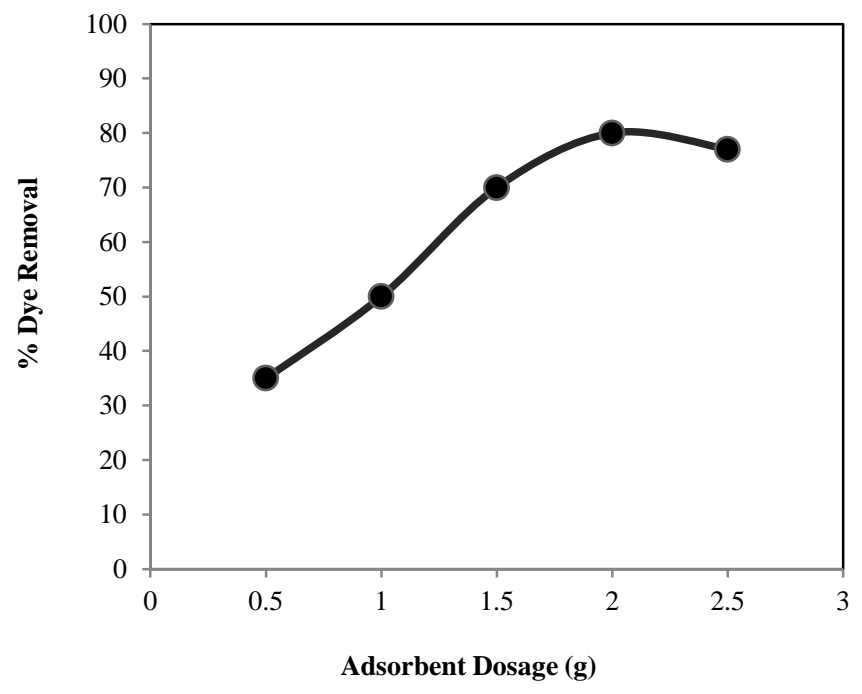

Figure 3: Effect of Adsorbent Dosage on Dye Adsorption Using Sawdust Activated Carbon [Ambient Temperature $=30{ }^{\circ} \mathrm{C}$; Agitation speed $=200$ rpm; Contact time $=\mathbf{7 5}$ mins $]$.

\section{Effect of Contact Time}

The percentage of dye removal as a function of time shown in Figure 4 indicated that, the percentage was found to increase from $32.7-75.3 \%$ as the contact time increases from $30-120 \mathrm{~min}$ at $15 \mathrm{~min}$ interval. The maximum removal was $75.3 \%$ corresponding to contact time of $85 \mathrm{~min}$. In the batch type adsorption processes, the monolayer of adsorbate is normally formed on the surface of adsorbent and the rate of removal is controlled primarily by the rate of transport of the adsorbate species from the exterior/outer site to the interior sites of the adsorbent particles (Kannan et al., 2001).

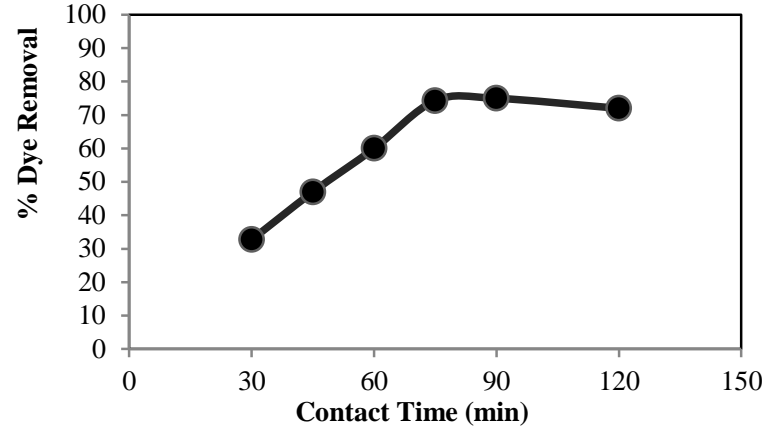

Figure 4: Effect of contact time on dye adsorption using sawdust activated carbon [Ambient Temperature $=30^{\circ} \mathrm{C}$; Agitation speed $=200$ rpm; Adsorbent dosage = 2 g] .

\section{CONCLUSION}

The activated carbon prepared from sawdust shows significant adsorption capacity for the removal of dyes from textile effluent treatment processes under suitable experimental conditions. The process was optimized, and the maximum dye removal of $98.5 \%$ was achieved at optimum conditions of $1.5 \mathrm{~g}, 90 \mathrm{~min}$, and $275 \mathrm{rpm}$ for adsorbent dose, contact time, and agitation speed respectively. The ANOVA response shows the reliability of the data with a good correlation coefficient $\mathrm{R}^{2}$ of 0.98 . It was also found that aside dye removal, the activated sawdust was also effective in the removal of trace metals. Sawdust is readily available at negligible cost and hence will serve as a useful low cost and environmentally benign adsorbent. The result will be useful for designing and fabricating an economically cheap treatment process plant for the removal of dyes and trace metals from industrial effluents.

\section{ACKNOWLEDGEMENTS}

The team acknowledges Prof. Omotayo Arotiba and his research assistant at the University of Johannesburg for the initial characterization of the raw water using ICP- MS. We also acknowledge the Technologists at the LNLG, Chemical Engineering and Central Research Laboratories who have facilitated in one way or the other, the completion of the research.

\section{REFERENCES}

Adewoye, L. T.; S. I. Mustapha, A. G. Adeniyi, J. O. Tijani, M. A. Amoloye and L. J. Ayinde. (2017). Optimization of nickel (II) and chromium (III) removal from contaminated water using sorghum bicolor. Nigerian Journal of Technology, 36(3): 960-972.

Allègre, C.; P. Moulin, M. Maisseu and F. Charbit. (2006). Treatment and reuse of reactive dyeing effluents. Journal of Membrane Science, 269(1):15-34.

Bhole, B. D.; B. Ganguly, A. Madhuram, D. Deshpande and J. Joshi. (2004). Biosorption of methyl violet, basic fuchsin and their mixture using dead fungal biomass. Current Science, 86(12): 1641-1645. 
Garg, V. K.; M. Amita, R. Kumar and R. Gupta. (2004). Basic Dye (Methylene Blue) removal from simulated Wastewater by Adsorption Using Indian Rosewwood Sawdust: a Timber Industry Waste. Dyes and Pigments. 62:243-250.

Grant, J. and Buchanan, I. (2000). Colour Removal from Pulp Mill Effluents Using Immobilized Horseradish Peroxidase. Project Report 2000-8. 1-17

Hettige, A. I. and Mowjood, M. I. M. (2015). Reduction of Colour in Treated Wastewater from Textile Industry Using Sawdusts as Bio-sorbents Tropical Agricultural Research, 26(4): 666-676.

Jin, X., G. and L., Xu, Z. (2007). Decolorization of a dye industry effluent by Aspergillus fumigatus XC6. Appl Microbiol Biotechnol, 74: 239-243.

Kannan, N. and Sundaram, M.M. (2001). Kinetics and Mechanism of Removal of Methylene Blue by Adsorption on Various Carbons - a Comparative Study. Dyes and Pigments 51: 25-40.

Khattri, S. D. and Singh, M. K. (2009). Removal of malachite green from dye wastewater using neem sawdust by adsorption. Journal of Hazardous Materials, 167(1): 10891094.

Kyzas, G. Z.; J. Fu and K. A. Matis. (2013). The Change from Past to Future for Adsorbent Materials in Treatment of Dyeing Wastewaters. Materials, 6: 5131-5158.

Malik, R.; D. S. Ramteke and S. R. Wate. (2007). Adsorption of malachite green on groundnut shell waste based powdered activated carbon. Waste Management, 27(9): 11291138.

Pang, Y. L. and Abdullah, A. Z. (2013). Current Status of Textile Industry Wastewater Management and Research Progress in Malaysia: A Review. Clean Soil Air Water, 41(8): 751-764.
Pearce, C. I.; J. R. Lloyd and J. T. Guthrie. (2003). The removal of colour from textile wastewater using whole bacterial cells: a review. Dyes and Pigments, 58: 179-196.

Pereira, L. and Alves, M. (2007). Dyes-Environmental Impact and Remediation. Trends Biotechnol., 6: 148-153.

Robinson, T.; G. McMullan, R. Marchant and P. Nigam. (2001). Remediation of dyes in textile e,uent: a critical review on current treatment technologies with a proposed alternative. Bioresource Technology, 77: 247-255.

Santhy, K. and Selvapathy, P. (2006). Removal of reactive dyes from wastewater by adsorption on coir pith activated carbon. Bioresource Technology, 97(11): 13291336.

Sun, Q. and Yang, L. (2003). The adsorption of basic dyes from aqueous solution on modified peat-resin particle. Water Research, 37: 1535-1544.

Suteu, D.; D. Bilba, C. Zaharia and A. Popescu. (2008). Removal of dyes from textile wastewater by sorption onto lignocellulosic materials. Scientific Study and Research, 9(3).

Tan, I. A. W.; A. L. Ahmad and B. H. Hameed. (2008). Adsorption of basic dye on high-surface-area activated carbon prepared from coconut husk: Equilibrium, kinetic and thermodynamic studies. Journal of Hazardous Materials, 154(1-3): 337-346.

Tan, I. A. W.; B. H. Hameed and A. L. Ahmad. (2007). Equilibrium and kinetic studies on basic dye adsorption by oil palm fibre activated carbon. Chemical Engineering Journal, 127(1): 111-119.

Wang, X.; X. Gu, D. Lin, F. Dong and X. Wan. (2007). Treatment of acid rose dye conatining wastewater by ozonizing - biological aerated filter. Dyes and Pigments, 74(3): 736-740. 